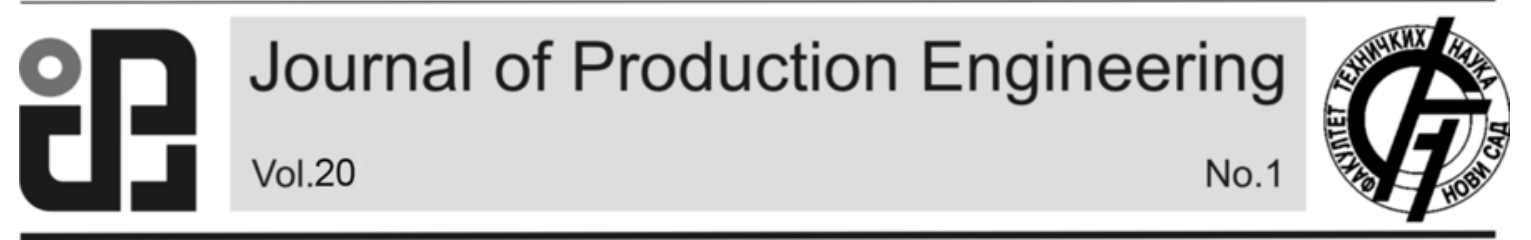

JPE (2017) Vol.20 (1)

Mácsay, V., Bányai T.

Preliminary Note

\title{
TOYOTA PRODUCTION SYSTEM IN MILKRUN BASED IN-PLANT SUPPLY
}

Received: 15 March 2017 / Accepted: 13 April 2017

\begin{abstract}
The optimization of manufacturing related logistic systems and processes is a key factor of the economical operation. The Toyota Production System (TPS), as precursor of the lean philosophy, is a well known tool to support the operation of manufacturing processes. However TPS includes the logistic processes of supply chain, but a wide range of TPS applications can be found in in-plant supply, especially in the field of automotive industry. After a careful literature review, the authors describe the impact of TPS on milkrun based in-plant supply. Next, a general milkrun morphology is presented, by the aid of which it is possible to describe typical in-plant supply processes. An evaluation method is also described to analyse the cost efficiency of the typical supply methods.
\end{abstract}

Key words: inventory, logistics, manufacturing, milkrun, supply

Toyota proizvodni sistem Milkrun baziran na snabdevanju fabrike. Optimizacija proizvodnih logističkih sistema i procesa je ključni faktor ekonomskog poslovanja. Proizvodni sistem Tojota (TPS), kao preteča lean filozofije, je dobro poznat alat za podršku rada proizvodnih procesa. Međutim TPS uključuje logističke procese lanca snabdevanja, ali širok spektar TPS aplikacije može se naći u ponudi snabdevanja fabrike, posebno u oblasti automobilske industrije. Nakon pažljivog pregleda literature, autori opisuju uticaj TPS na Milkrun sistem baziranih ponuda snabdevanja fabrike. Sledeće, opšta Milkrun morfologija je predstavljena, pomoću koje se može opisati tipičn proces snabdevanja fabrike. Takođe je opisan metod evaluacije za analiziu efikasnost troškova tipične metode za snabdevanje.

Ključne reči: inventar, logistika, proizvodnja, milkrun, snabdevanje

\section{INTRODUCTION}

Logistics can be divided into four main parts: purchasing, production, distribution and recycling. Production logistics is placed in the middle of the supply chain, so the characteristics of suppliers and customers has an impact on the efficiency of the production related logistic processes. The purposes of production logistics are the followings: (1) increased utilization of manufacturing and logistic resources; (2) decreased lead-time of products and losts; (3) decreased inventory in the manufacturing process; (4) decreased costs; (5) increased flexibility of the manufacturing and related logistic process; (6) increased transparency to support lean philosophy based solutions; (7) increased quality of products; (8) integration of the production logistics into the enterprise resource planning (ERP) system.

The material supply of machines in a manufacturing system can be realised in many ways. In the last few years, the milkrun-based in-plant supply is widely spread, especially in the field of the automotive industry. Milkrun supply makes it possible to fed manufacturing and assembly workstations keeping on the $7 \mathrm{R}$ rule: the right product, in the right quantity and condition, from the right place, at the right time, to the right place, for the right costs.

Where did the idea of milkrun come from? As it can be deducible from its name, the milkrun idea had been gained from an old version of milk delivery. The milkman distributed the full bottles and collected the empty bottles. If you left him two empty bottles in front of the door then he put two full bottles of milk instead of them. After it the milkman returned with the empties back to the starting point where bottles had been refilled.

This method spread more and more between international companies as both the delivery to customers and the return are making value. The fierce competition between companies claim to eliminate the non-value added activities. What does bottle symbolise? It symbolises the empties. The companies have to pay a large amount of environmental product fee for packaging, so they try to use more reusable packagings. When the customer own the empties, the truck takes the pallets, boxes, containers to the supplier company where they are loaded with the requested quantity of the product. When the truck goes back to the customer, they discharge the empties and the process starts from the beginning again. The design and operation of milkrun based in-plant supply include a wide range of problems: location of stores, supermarkets and machines; routing of milkruns; scheduling; assignment of machines, products, milkruns and operators; inventory optimisation, queuing problems.To our best knowledge, the design of milkrun based in-plant supply of manufacturing plants has not been considered in the current literature.

The main contribution of this work include: (1) the description of the impact of TPS on milkrun based inplant supply including 5S (seiri, seiton, seiso, seiketsu, shitsuke), kaizen and 3MU (muda, mura, muri); (2) the morphology of milkrun based in-plant supply including the sources, milkruns, machines and strategies; (3) the 
description of typical milkrun based supply solutions; (4) an evaluation method to analyse the supply solutions from the point of view costs, efficiency, performance and reliability.

\section{LITERATURE REVIEW}

This section reviews relevant literature related to TPS and milkrun based supply. Due to the large amount of researches on these fields, the most relevant scientific results have to be summarized before to elaborate impacts, morphology and typical models.

There are integrated approaches of TPS to include the rules or principles underlying TPS strategies [1]. These works are focusing on the fact, that few companies are able to apply TPS strategies successfully. However TPS is widely used in the field of automotive industry, but there are successful applications in other fields, like services [2]. The milkrun based supply is a common in-plant supply strategy in the field of automotive industry and assembly companies, where vehicles circulate between component sources (warehouses or storages) and production or assembly plants according to the supply strategy based on just-in-sequence philosophy [3].

The design of milkrun based in-plant supply includes a huge number of optimisation problems: facility location of supermarkets or pick-up stations; routing [4] of external or internal milkrun vehicles; scheduling. However analytical and heuristic methods are suitable to solve design and control problems of milkrun based in-plant supply, but in many cases simulation based optimisation is the best tool to find optimal solutions of the problems related to milkrun operation [5]. The in-plant supply problems can be defined as NP-hard problems and most of them can be solved with different metaheuristics, like genetic algorithms, evolution strategies, ant colony optimisation, firefly algorithm, cuckoo search, harmony search, etc [6].

The most important tasks of manufacturing and assembly companies are the followings: manage their external and internal supply chain efficiently, increase profit and improve the quality and efficiency of delivery and in-plant supply through production strategies like JIT and JIS. The milkrun concept is the best tool to support JIS in-plant supply, including the following advantages: increased efficiency of material handling processes (storage, transportation, loading, unloading, packaging), up-to-date identification solutions, demand-based feeding process of production and assembly stations, decreased in-process inventory.

The just-in-sequence supply based on milkrun vehicles can be divided into two main streams. The first stream is represented by static assignment and route design while the second stream can be described as dynamic, flexible process including realtime milkrun routing and scheduling $[7,8]$.

The milkrun based in-plant supply has a wide range of object included in the supply process, like warehouses, supermarkets, production stations, inprocess storages, empty bin storages [9]. The operation strategy of the different milkrun solutions depends on the structure. The different strategies for handling delivery peaks can be evaluated with respect to operation costs (including technical and human resources), lead time, inventory in warehouses and inprocess storages and service level [10].

The aim of this paper is to investigate the impact of TPS on the performance of milkrun based in-plant supply. The contribution of this paper to the literature is twofold: description of a morphology including structural and process-oriented parameters; development of an evaluation method to analyse the different supply methods.

This paper is organized as follows. Section 2 presents a literature review, which systematically summarizes the research background of milkrun based supply. Section 3 describes the impacts of TPS on milkrun based supply. Section 4 presents the morphology of possible milkrun based in-plant supply solutions including technological and logistic resources. Section 5 demonstrates the most important in-plant supply processes and strategies. For our study, in Section 6 we focus on an evaluation method to analyse the performance of different solutions. Conclusions and future research directions are discussed in Section 7.

\section{TPS IMPACT ON MILKRUN BASED SUPPLY}

Pull-system, kanban-system and just-in-time can be implemented perfectly through the milkrun concept. When the stock of the users is below the required level, they send a truck with the necessary amount of empties in it.

The milkrun concept can use not only the delivery between companies and customers but also in the inplant supply. You can attach any number of wagon to a milkrun so it is easy to change the capacity. Its other advantage is that different kind of boxes, pallets and so one can be transported by it. They supply not only the manufacturing cells but also collect the empty packagings from them.

So the milkrun can increase the rate of value add activities in the in-plant supply chain. The introduction of milkrun can help to improve the processes of the Present State Value Stream Map and to reach the Future State Value Stream Map. Now, see how to milkrun can implement the 5S-Method:

Seiri (Sorting): The milkrun is able to take the necessary components to the manufacturing cells, and to collect the redundant materials, boxes and other packagings.

- Seiton (Setting in order): The milkrun is able to supply more manufacturing cells in one round and to do it in the most satisfactory order. We can determine the place of the different components and packaging on the vehicles too.

- Seiso (Shining): Wagons can be unplugged and replaced, so they can be cleaned easily. Beside of it, the milkrun helps to keep the tidiness of manufacturing cells, as it collects the redundant materials and transport them to an empty bin storage.

- Seiketsu (Standardizing) Standards can be 
introduced for the supply method, the schedule and the route of the milkrun can be standardised in the case of static operation strategies.

- Shitsuke (Sustaining) The established standards have to be sustained and taught.

The kaizen philosophy in the milkrun includes the following aspects:

- Shortening: You can supply more cells with a milkrun than with a forklift or with a pump truck.

- Linking and simplifying processes: You can take different kind of components, packaging and waste on one milkrun.

- Flexibility: You can change flexibly the order of cells supplying. You can't do it with a conveyor.

However beside its positives the milkrun concept can be the source of wastes too.

The $3 \mathrm{MU}$ in the milkrun includes the following aspects:

- Muda consists of The Seven Wastes: transport, inventory, motion, waiting, overproduction, overprocessing, defects. Most of them can appear in the milkrun method, for example, we take too much or too little component to the cells, we delay, we have to take back materials to the warehouse because of a sudden SMED, etc.

- Mura is The Waste of Unevenness: The cells need very different and fluctuant component quantities and the milkrun can't cope with it.

- Muri is The Waste of Overburden: For example the milkrun have to supply too many cells and the delays cause the shortages of components in the cells.

Ideally, the milkrun would be able to supply the cells according to a defined schedule. It can be able to take the components in the manufacturing cells just in time.

Implementation of it needs a huge amount of information, for example:

- How many units of components have been placed in a cell?

- How many parts are in a unit?

- How many parts need for example for an hour?

\begin{tabular}{ccccccc}
\hline Product ID & $\begin{array}{c}\text { Number of } \\
\text { boxes }\end{array}$ & Pcs/bin & Total amount & $\begin{array}{c}\text { Speed of } \\
\text { through-put }\end{array}$ & $\begin{array}{c}\text { Required upload } \\
\text { rate }\end{array}$ & $\begin{array}{c}\text { Speed of through-put of } \\
\text { bins }\end{array}$ \\
\hline 1 & 3 & 45 & 75 & 20 pcs/hours & 3,75 hours & 2,25 \\
2 & 4 & 32 & 128 & 20 pcs/hours & 6,4 hours & 1,6 \\
3 & 1 & 4000 & 4000 & 80 pcs/hours & 50 hours & 50 \\
4 & 1 & 4000 & 4000 & 20 pcs/hours & 200 hours & 200 \\
5 & 3 & 100 & 300 & 40 pcs/hours & 7,5 hours & 2,5 \\
6 & 12 & 12 & 144 & 20 pcs/hours & 7,2 hours & 0,6 \\
7 & 6 & 12 & 72 & 60 pcs/hours & 1,2 hours & 0,2 \\
\hline
\end{tabular}

Table 1. Dataset for a case study of milk-run based supply of manufacturing machines

As we can see from the table, it is sufficient to recharge the 1), 2), and 5) components in every 4,5 hours. In that case, we have still one box for emergency. If we have only 8 or 9 units from the 6) component in the cells it will be fit to this time too.

The introduction of the milkrun concept is a very good idea, but we can reach the highest possible efficiency only if we do the necessary analysis and calculations. We have to know for example which the best route is, or which the best upload rate is. We have to make standards and instructions. One milkrun can supply either 10 or 20 manufacturing cells, so the coordination is a very complicated task. We need a large amount of information and data to be able to set up an efficient system. The cells usually have a different upload rate; they can make different products by different operations.

We have to assess the following: the route of the milkrun operator, the most effective direction of the route, the best order of supplying. We have to take into consideration the period required for the supplying, collecting the left-over components and waste of packagings from the cells. We have to find a balance between the frequency of upload and the number of milkrun operators.

The efficiency of the milkrun is influenced significantly by the method of order picking in the warehouse. It can be solved in one or two steps. When we fulfil it in one step the milkrun operator is the order picker too. The operator collects the required components in the warehouse and then takes them to the manufacturing cells. In the two steps version, we distribute the two activities between two operators, one prepares the orders in the warehouse and the other takes it to the cell. We have to take into consideration the most practical rate of order pickers and milkrun operators. Depending on the specifics of the company the ratio of order pickers to milkrun operators can be other than $1: 1$, for example, it can be $2: 3$ or $1: 2$. In the two steps version coordination of the work is very important to avoid waiting time.

We can use different methods in the supply too, for example, supply according to a fix schedule. Maybe we will take into consideration the number of empty boxes and other empties in the cells when we make the next component order.

The aim is to implement the just-in-time strategy and to reduce the component stocks in the cells. When the assembly workers have only the necessary components in the cells, it makes their work easier as they have more place and it increases the transparency of processes. According to it, the milkruns have to take a small amount of components to the manufacturing cells and they have to take them frequently. It is important to remove from the cells the unnecessary materials, packagings and the defect parts or products. 
We have to investigate why they have remained in the cells so far.

It is essential too that we have the proper shape and size shelves, supermarkets and so one in the cells. The wrong layout can cause difficulties both to the milkrun operators and to the assembly workers. When we create a storage facility, it can be useful to implement the First in First out method.

In order to make rules and standards in the component supply chain sometimes we have to change the quantity of the components in the cells and we have to create new storage facilities or we have to remove old ones. Ideally, the rate of uploads is the submultiple of the shift and it counts with the breaks too.

When all the mentioned conditions are right we still have problems which have to solve. These are the following:

- The assembly workers work slower than they should work and because of its components pile up.

- The assembly workers work quicker than they should work and because of its components run out in the cells.

- The manufacturing cell have to change from a product to another one and because of it the milkrun operator has to remove the previous component and then take the new component to the cell.

In order to solve the first problem, we have to keep in the manufacturing cells more smaller units instead of few bigger units. In that case, we are able to upload the required quantity of components. We can keep the superfluous component on the wagon so in the end of the shift, we will see how many components remain. We can investigate what the cause of it, maybe the assembly workers are overburdened and we have to change the rate of upload.

The other solution is to upload the cells according to the empty boxes and other empties.

As in the pull-system, we need to produce only a certain number of end product we don't have to make more. This kind of waiting of the assembly workers don't cause waste, but if it is a usual problem and we need more capacity somewhere else we can change the rate of upload.

Unfortunately, the milkrun can't cope with the third problem. The milkrun supplies the cells according to a schedule and the urgent cases disturb this process. We have to separate the scheduled processes from the urgent cases as we separate the public transport from the ambulance.

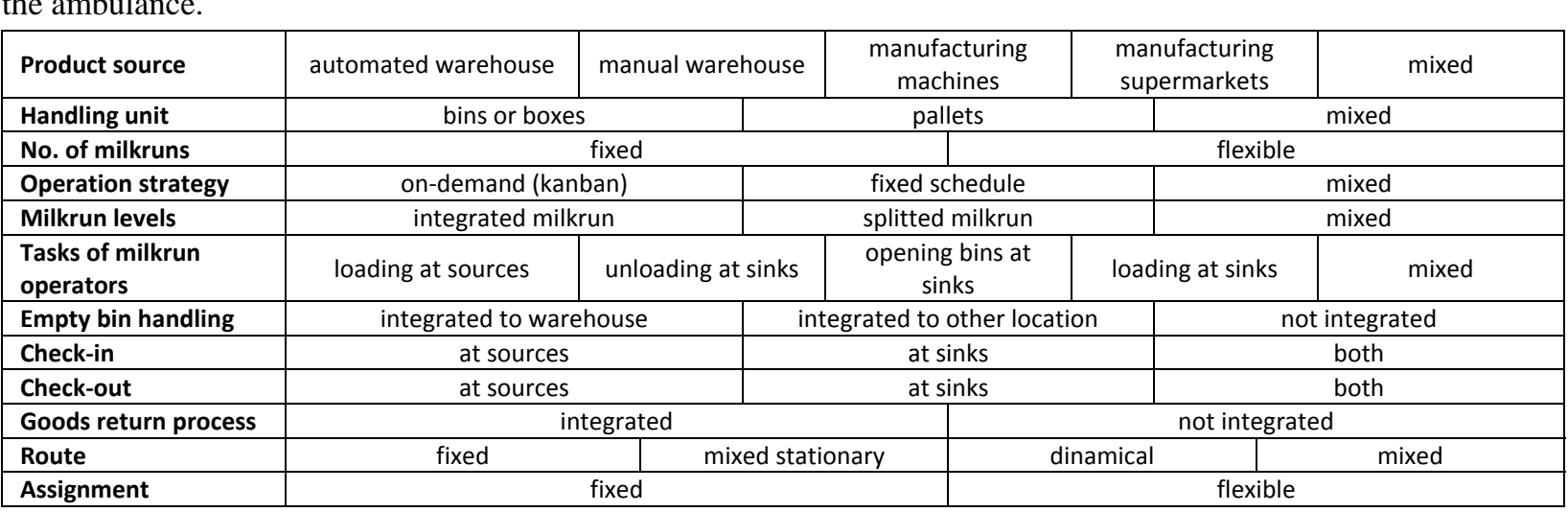

Table 2. Morphology of milkrun based supply of assembly stations
It can be a good solution if we use forklifts or pump truck for emergency situations.

\section{MORPHOLOGY OF MILKRUN SUPPLY}

It is possible to define different parameters and characteristics, by the aid of which it is possible to build a general model structure of milkrun based supply [11]. The below-described general model represents the morphology of the milkrun based component supply of an assembly plant. The component sources of assembly stations (sinks) can be automated or manual warehouses, supermarkets or machines in manufacturing plants. The handling units of products are either boxes (bins) or pallets, but it is also possible to use mixed handling units, especially in the case of a wide range of macrogeometry of components. The number of milkruns depends on the required component supply performance. If the required performance is variable, the number of milkruns is flexible; in other cases the number of milkruns can be fixed. One of the most important characteristics of the supply is the operation strategy. There are different types of operation strategies; the most widely used strategies are the on-demand strategy and the fixed schedule strategy. If the source of components is placed in warehouses, it is possible to split the tasks of milkrun supply and define two stages: the first stage is the internal milkrun which perform the picking process in the warehouse; the second stage is the external milkrun, which performs the feeding of assembly stations. The milkrun operators can perform a wide range of operation tasks, like loading at sources, unloading at sinks, opening loading units and boxes at assembly stations, loading goods return, final products, empty bins or wrapping at assembly stations. The integration of empty bin handling depends on the operation strategy; a wide range of milkrun based supply the empty bin handling is not integrated into the milkrun process. From the point of view warehouse management, we can also define some important parameters: check-in and check-out location of components. Route planning is a very important part of the design of material handling systems. In the case of milkrun supply routes can be fixed, mixed stationary or dynamical. The assignment of milkruns to assembly stations, warehouses, components or operators is also an important characteristics of milkrun supply. 


\section{MILKRUN BASED SUPPLY STRATEGIES}

Within the frame of this chapter, the authors describe four different milkrun based supply. These scenarios represent the most widely spread solution in the field of assembly plant supply.

Scenario one is based on an external milkrun. The source of components is an automated warehouse, where the required components are collected and placed on a pick-up area. In this case, there are no internal milkruns in the warehouse. The milkrun feeds the assembly stations and the external bin storage with empty bins from assembly stations. In this scenario, the check-out process is located at the exit of the warehouse.

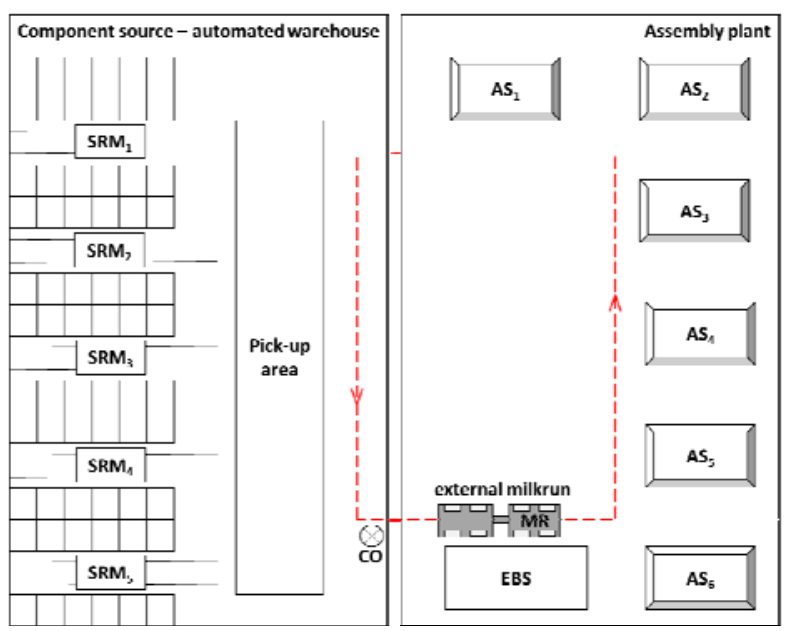

Fig. 1. Scenario1 with external milkrun

In the case of scenario two the collection of required components and the supply of assembly stations is based on an integrated milkrun. The operator is responsible for the whole material supply process from picking through supply to the handling of empty bins and pallets. In this case, the components are checked out at the assembly stations.

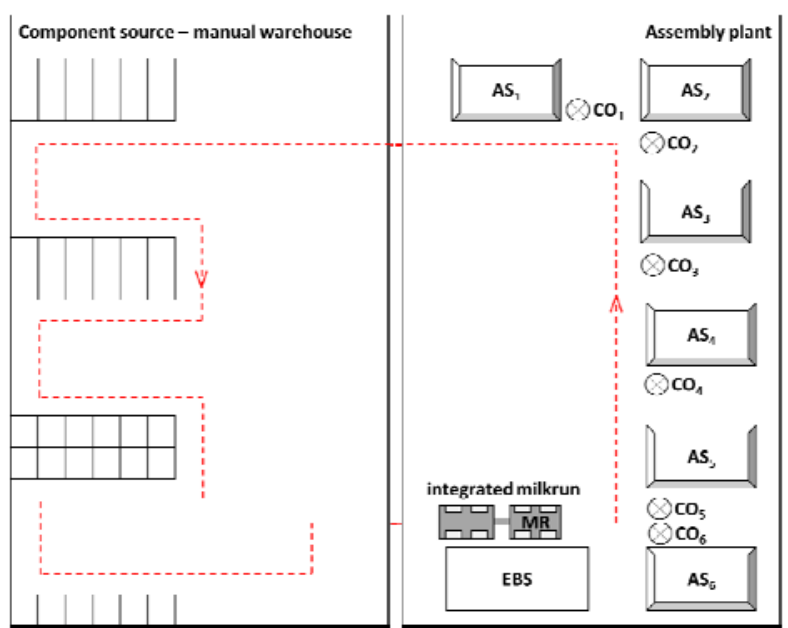

Fig. 2. Scenarion 2 with integrated milkrun

In the case of scenario three, the collection and supply process is divided into two rounds: internal and external milkruns. In this case, components are checked out at the pick-up area, where the external milkrun operator changes vehicles. The divided milkruns make it possible to decrease the cycle time of milkruns, but more operator is required. An additional design aspect is to match the cycle time of collection process with the cycle time of the external milkrun.

Scenario four represents a complex source of required components. Components can be collected both warehouses and manufacturing plants. In general cases, the pick-up location of required components is the output supermarket of the manufacturing plant. In special cases, components can be collected from manufacturing machines, but in this case, the collection route and the cycle time of collection process is greatly increased. The check-out of required components is located in two different places; warehouse for stored components and manufacturing plant for produced components. The handling of empty bins or pallets are not integrated into the milkrun routes, therefore an additional vehicle (e.g. forklift) is required for this material handling task.

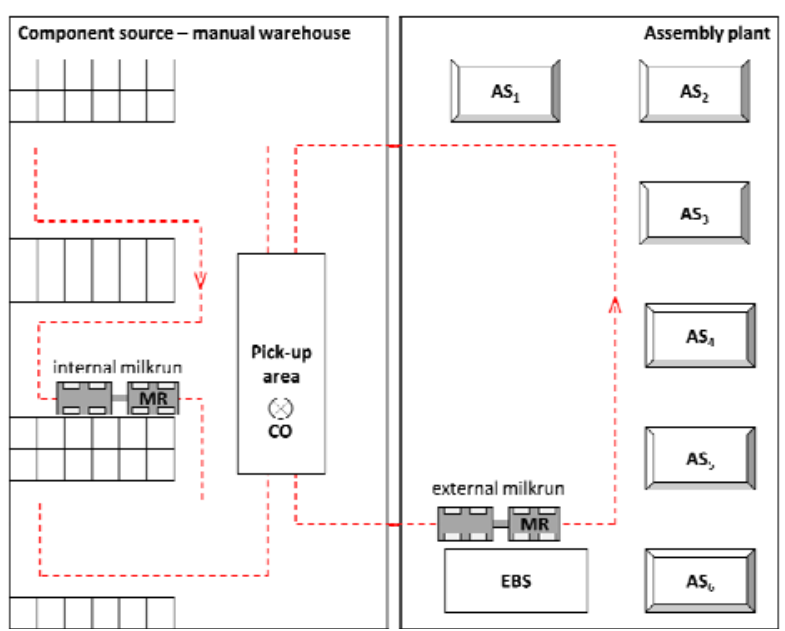

Fig. 3. Scenario 3 with two-level milkrun

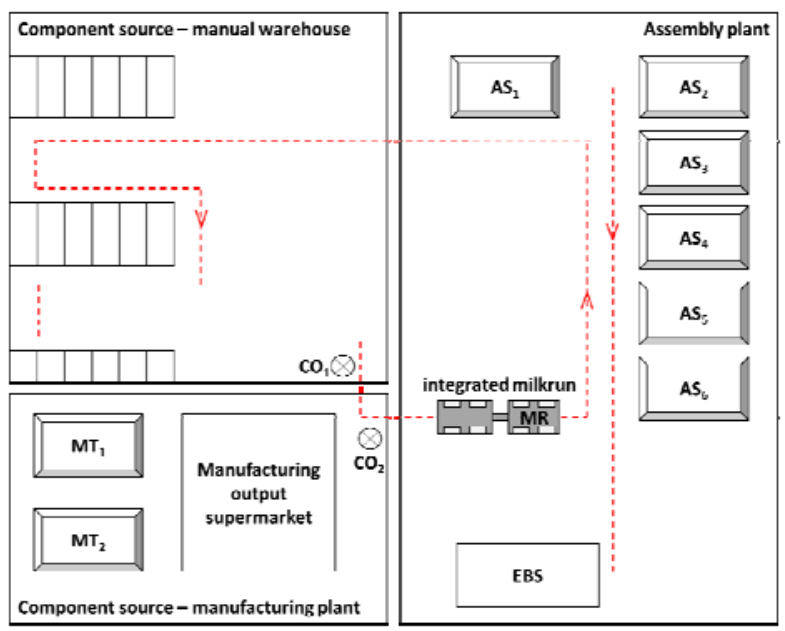

Fig. 4. Scenario 4 with integrated milkrun

\section{EVALUATION MODEL}

Within the frame of this chapter, the general aspects of an evaluation method are described, by the aid of which it is possible to analyse the different solutions of milkrun based component supply of assembly plants.

It is possible to evaluate the milkrun supply from 
the point of view time, cost, efficiency and performance. The below-described method is focusing on time-based evaluation. As Table 3 shows, we can define different processes of the milkrun supply.

\begin{tabular}{llcccc}
\hline Operation & & S1 & S2 & S3 & S4 \\
\hline collection & $t_{c}$ & + & ++ & ++ & +++ \\
pick-up & $t_{p u}$ & + & & & \\
check-out & $t_{c o}$ & + & +++ & + & + \\
running time of milkrun & $t_{r m}$ & + & ++ & + & +++ \\
unloading of components & $t_{u c}$ & + & + & + & + \\
opening bins & $t_{o b}$ & + & + & + & + \\
loading empty bins & $t_{l e b}$ & + & + & + & \\
unloading empty bins & $t_{u e b}$ & + & + & + & \\
loading goods return & $t_{l r}$ & + & + & + & + \\
unloading goods return & $t_{u r}$ & + & ++ & & ++ \\
empty bin handling vehicle & $t_{e v}$ & & & & + \\
\hline
\end{tabular}

Table 3. Time span components of milkruns (number of + means small, medium or large time span)

Depending on the schedule of the different operations, it is possible to calculate the cycle time of the milkrun and evaluate each solution.

In the case of overlapped operations, the cycle time can be decreased. However this solution can ensure higher efficiency and performance, but the costs of overlapped operations, like two level milkrun and collection in automated warehouses, increase the costs caused by increased number of required operators or expensive technology.

Depending on the required upload rate by each assembly station and the speed of throughput of components and bins the cycle time and the related costs can be calculated.

\section{CONCLUSIONS}

As a very delicious and complicated food which preparation needs a lot of experience and attention, the milkrun method requires a very good planning and implementation to be well-organised and efficient.

Of course, this requires a lot of experience, calculations and tests. The human factor is also an important part of the process as we need operators who understand, support and follow the rules and standards.

In conclusion, the milkrun method can be a practical part of the TPS as it can implement the pullsystem, the 5S, the continuous material flow and the kaizen principles. To continuous improvement, we have to examine emerging problems, find the cause and the solution of them.

\section{REFERENCES}

[1] Jayaram, J., Das, A., Nicolae, M.: Looking beyond the obvious: Unraveling the Toyota production system. International Journal of Production Economics, 128(1) pp.280-291. 2010

[2] Stapleton, B. F., Hendricks, J., Hagan, P., Del Beccaro, M.: Modifying the Toyota Production System for Continuous Performance Improvement in an Academic Children's Hospital. Pediatric Clinics of North America, 56(4) pp.799-813. 2009

[3] Kovács, A.: Optimizing the storage assignment in a warehouse served by milkrun logistics.
International Journal of Production Economics, 133(1) pp. 312-318. 2011

[4] Gyulai, D., Pfeiffer, A., Sobottka, T., Váncza, J.: Milkrun Vehicle Routing Approach for Shop-floor Logistics. Procedia CIRP, 7 pp. 127-132. 2013

[5] Wiegel, F., Immler, S., Knobloch, D., Abele, E.: Simulation-based optimization of internal Milkruns: Development of a simulation model for planning and optimizing the provision of material. Productivity Management 18(1) pp. 51-54, 2013

[6] Jafari-Eskandari, M., Sadjadi, S.J., Jabalameli, M.S., Bozorgi-Amiri, A.: A robust optimization approach for the milk run problem (an auto industrysupply chain case study). International Conference on Computers and Industrial Engineering, pp. 1076-1081, 2009

[7] Kitamura, T., Okamoto, K.: Automated route planning for milk-run transport logistics using model checking. Proceedings of the 2012 3rd International Conference on Networking and Computing, pp. 240-246, 2012

[8] Satoh, I.: A formal approach for milk-run transport logistics. IEICE Transactions on Fundamentals of Electronics, Communications and Computer Sciences pp. 3261-3268, 2008

[9] Vieira, A., Dias, L.S., Pereira, G.B., Oliveira, J.A., Carvalho, M.S., Martins, P.: Automatic simulation models generation of warehouses with milk runs and pickers. Proceedings of the 28th European Modeling and Simulation Symposium, pp. 231-241, 2016

[10] Klenk, E., Galka, S., Giinthner, W.A.: Operating strategies for in-plant milk-run systems. 15th IFAC Symposium on Information Control Problems in Manufacturing. pp 1882-1887, 2015

[11] Klenk, E., Galka, S., Günthner, W. A.: Analysis of parameters influencing in-plant milk run design for production supply, Proceedings of the International Material Handling Research Colloquium, pp. 25-28, 2012

\section{ACKNOWLEDGEMENTS}

The described research was carried out as part of the EFOP-3.6.1-16-00011 "Younger and Renewing University - Innovative Knowledge City - institutional development of the University of Miskolc aiming at intelligent specialization" project implemented in the framework of the Szechenyi 2020 program. The realization of this project is supported by the European Union, co-financed by the European Social Fund.

Authors: Vivien Mácsay BSc, Tamás Bányai PhD, Assoc. Professor, University of Miskolc, Faculty of Mechanical Engineering and Informatics, Institute for Logistics, Miskolc-Egyetemváros, 3515, Hungary, Phone.: +36 46 565-111, Fax: +36 46 565-111.

E-mail: alttamas@uni-miskolc.hu vivienmacsay@gmail.com 